ENTREPRENEURSHIP AND SUSTAINABILITY ISSUES

ISSN 2345-0282 (online) http://jssidoi.org/jesi/

2019 Volume 7 Number 2 (December)

http://doi.org/10.9770/jesi.2019.7.2(57)

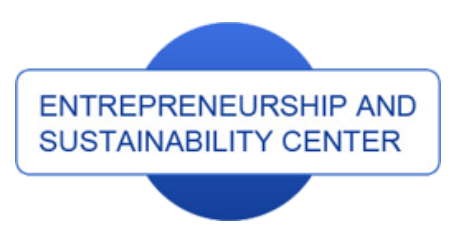

Publisher

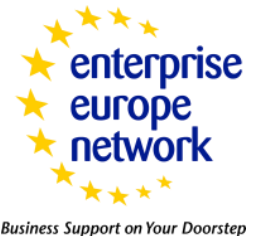

CASPA

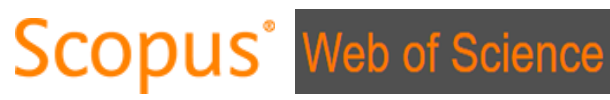

http://jssidoi.org/esc/home

Business Support on Your Doorstep

1) Clarivate

Analytics

\title{
INFLUENCE OF SOCIAL PARTNERSHIP ON THE DEVELOPMENT OF ENTERPRISE: ON THE EXAMPLE OF OIL INDUSTRY
}

\author{
Alisher Sansyzbayev \\ Narxoz University, Zhandosov st. 55, Almaty, Kazakhstan \\ E-mail: centrino-018@mail.ru
}

Received 16 August 2019; accepted 22 November 2019; published 15 December 2019

\begin{abstract}
At the present stage of development, global trends are characterized by updating the content and modernization of the forms of labor activity, organization of production and management. This finds expression in the organization of social partnership. The accumulated potential of theoretical knowledge and practical experience on the issue under study is crucial for the development of ways and mechanisms of interaction between the state and business, especially in the oil industry of Kazakhstan. The article discusses the impact of social partnership on the development of enterprises on the example of the oil industry of the Republic of Kazakhstan, as a sociopolitical institution that ensures the interaction of the state, business, and trade unions in modern Kazakhstani society. The analysis of the interaction of subjects of social partnership both in the field of labor relations and in the sphere of public relations is carried out, the institutional capabilities of the oil industry enterprises as subjects of social partnership, the importance and impact of social partnership policies on the democratization processes, social and political stability of Kazakhstani society are analyzed.
\end{abstract}

Keywords: oil industry; social partnership; trade union; system; management

Reference to this paper should be made as follows: Sansyzbayev, A. 2019. Influence of social partnership to the development of enterprise (on the example of oil industry), Entrepreneurship and Sustainability Issues, 7(2), 1613-1627. http://doi.org/10.9770/jesi.2019.7.2(57)

JEL Classifications: G23, O13.

\section{Introduction}

Social partnership is a special ideology and idea of the nature of the interaction of classes in a market-capitalist economy, which was formed within the framework of the social democratic, reformist movement in the labor movement (Mukhambetova 2014).

The content of the term "social partnership" in the scientific literature is defined ambiguously. So, for example, some researchers, such as L.A. Gordon, consider social partnership as a method and mechanism for regulating social and labor relations, resolving contradictions between workers and employers (Gordon 2015). 


\section{Literature review}

Other researchers, such as S.P. Peregudov, believe that this is one of the most common types of corporatism of neo-corporate relations that arise between representatives of three main subjects - business, trade unions and the state. At the same time, they classify social partnerships according to various systems: "tripartism", "bipartism", micro- and mesocorporatism (according to the levels of individual corporations, industries and regions) (Peregudov 2016).

Vetrov A.V. characterizes social partnership as a complex social phenomenon, a multifaceted contradictory social process that arises between workers, employers and government (Vetrov 2015).

The most radical researchers, such as M. Voeikov, I. Lashchinsky, who hold the idea of the inevitability of social conflicts in the manufacturing sector, argue that the interests of owners-employers can be satisfied only at the expense of the interests of workers (Voeikov and Lashchinsky 2016).

I.N. Sycheva notes that social partnership is a collaborative method of achieving goals and interests in social and labor relations by staff and employers" (Sycheva 2016).

According to Leontieva A. G., social partnership is a special system of relations between staff and employers with the regulatory role of the state, which is aimed at coordinating material interests and resolving social and labor conflicts, effectively operates within the framework of the relative balance between labor and capital (Leontieva 2017).

In his publications Pshenichny S.P. writes that social partnership as a system of interaction between the state, business and civil society is under the close attention of modern researchers and is considered as an interdisciplinary concept and affects both the social and economic sphere of society (Pschenichny 2015).

Taking into account international experience, in recent years in Kazakhstan a multilevel system and the legislative basis of social partnership have been formed. The current legal framework serves as the basis for partnerships and balancing the interests of workers and employers, and provides a civilized procedure for building and regulating labor relations between the main subjects of the labor market: employers, employees and the state (Ministry of Labor).

According to the definition of the Federation of Trade Unions of the Republic of Kazakhstan, social partnership is a system of relations between: workers (representatives of employees), employers (representatives of employers), and government bodies aimed at ensuring coordination of interests on issues of regulation of labor and socioeconomic relations and is provided in the form of interaction between the parties through social partnership bodies:

- at the republican level - by the Republican tripartite commission on social partnership and regulation of social and labor relations;

- at the industry level - by industry commissions for social partnership and the regulation of social and labor relations;

- at the regional (regional, city, district) level - by regional, city, district commissions for social partnership and the regulation of social and labor relations (Table 1) (Federation Trade Union). 


\section{ENTREPRENEURSHIP AND SUSTAINABILITY ISSUES}

ISSN 2345-0282 (online) http://jssidoi.org/jesi/

2019 Volume 7 Number 2 (December)

http://doi.org/10.9770/jesi.2019.7.2(57)

Table 1. Forms of interaction between the parties through social partnership bodies in the Republic of Kazakhstan

\begin{tabular}{|c|c|c|c|}
\hline Levels & Parties & Apparatus & Instruments \\
\hline Republician & $\begin{array}{c}\text { Government of the Republic } \\
\text { of Kazakhstan, NCE } \\
\text { (National Chamber of } \\
\text { Entrepreneurs) }\end{array}$ & $\begin{array}{c}\text { Republican Tripartite } \\
\text { Commission }\end{array}$ & Industry agreement \\
\hline Industry & $\begin{array}{c}\text { Ministry, Sectoral Trade } \\
\text { Union, NCE (National } \\
\text { Chamber of Entrepreneurs) }\end{array}$ & $\begin{array}{c}\text { Industry Tripartite } \\
\text { Commission }\end{array}$ & Regional agreement \\
\hline Regional & $\begin{array}{c}\text { Akimat, territorial union of } \\
\text { trade unions, NCE (National } \\
\text { Chamber of Entrepreneurs) }\end{array}$ & $\begin{array}{c}\text { Regional Tripartite } \\
\text { Commission }\end{array}$ & Collective agreement \\
\hline
\end{tabular}

Source: compiled by authors according to Data of the Federation of Trade Unions of the Republic of Kazakhstan www.fprk.kz

We can agree with the opinion of Aitbay K., who in his publications notes that the development of social partnership in its various forms is an important part of the process of strengthening the social orientation of the modern market economy. It is the conditions of social partnership that are considered as a kind of public shock absorber for tough market realities, since they combine the requirements of economic efficiency and the interests of social justice (Aitbay 2014).

Recently, social partnership is acquiring new features, being present not only in the labor sphere, but also manifesting itself as a new social phenomenon, the essence of which lies in the process of intersectoral interaction of government bodies, business and non-governmental organizations in order to resolve the most pressing social problems of society, as in national and local level.

In general, according to A. Amrebaev, over the years of the country's independent development, legislative support has been provided for decent work, a new model for regulating labor relations has been adopted that provides the optimal combination of protecting labor and social rights with economic feasibility, and an institutional and legal framework has been formed for the development of social partnership (Amrebaev 2015).

Shaltykov A.I., studying the problems of social partnership in Kazakhstan, claims that today Kazakhstan has developed certain mechanisms for the formation of a system of social partnership in the world of work:

- legislative registration of social partnership in the laws and regulations of the republic;

- the ongoing negotiation process between representatives of workers (trade unions), associations of employers and public authorities;

- permanent commissions (tripartite) on the regulation of social and labor relations;

- normative consolidation and compliance with the procedures for harmonizing the interests of the parties;

- a system for monitoring the implementation of adopted agreements and contracts (Shaltykov 2015).

The wise use of instruments of social partnership allows the state to reduce the budget load, ensure the development of infrastructure, increase the level of employment, develop private entrepreneurship and, at the same time, improve the quality of goods and services.

Thus, social partnership is one of the ways of civilized, peaceful coexistence of the state, business and civil society, maintaining social stability of the society.

\section{Methodology}

Today's Kazakhstani practice shows that the level of development of partnerships of various socio-political groups largely depends on the ability of the state to regulate the process of establishing a system of social 


\section{ENTREPRENEURSHIP AND SUSTAINABILITY ISSUES}

ISSN 2345-0282 (online) http://jssidoi.org/jesi/

2019 Volume 7 Number 2 (December)

http://doi.org/10.9770/jesi.2019.7.2(57)

partnership. Today, our state is working to ensure employment and reduce poverty in the country. For this purpose, active measures to promote employment, the organization of public works, vocational training for the unemployed, microcredit and much more are widely used. At the same time, the country has developed numerous programs to combat poverty, programs aimed at creating new jobs, etc.

Social partnership involves material and moral stimulation of the interest of employees in the growth of production rates, labor productivity in the name of providing the conditions necessary for the growth of employers' profit and gross domestic product, improving the level and quality of life of workers themselves. Complementing this palette is the opening of new enterprises with appropriate working conditions and, as a result, the creation of new jobs.

Social partnership has a great influence on the development of enterprises, including enterprises of the oil industry of the Republic of Kazakhstan. Studying the impact of social partnership on the oil industry, we note that the oil and gas industry plays an important role in the economy of Kazakhstan and is one of the main drivers of the country's GDP growth, reflecting the significant dependence of the economy on industry revenues.

In order to ensure stable and efficient activity of industry organizations in accordance with the Constitution of the Republic of Kazakhstan, the labor legislation of the Republic of Kazakhstan, the Law of the Republic of Kazakhstan "On Trade Unions", the Conventions of the International Labor Organization ratified by the Republic of Kazakhstan, a Sectoral Agreement on social partnership in oil and gas, oil refining was developed and concluded and petrochemical sectors of the Republic of Kazakhstan for 2017-2019, which provides for the procedure, the main the principles of remuneration of labor, social guarantees, compensation and benefits, as well as the development of social partnership in Kazakhstan (Industry agreement, Constitution, Law on Trade).

According to the Committee on Statistics of the Ministry of National Economy of the Republic of Kazakhstan, as of January 2019, 297 companies engaged in the production of coke and oil products are registered in Kazakhstan, of which 173 are active. Of the total number of companies engaged in the production of coke and oil products, they are divided into:

- Large enterprises (employees of more than 250 people) - 7 (including 7 operating);

- medium-sized enterprises (from 101 to 250 people) - 10 (7);

- small enterprises (from 5 to 100 people) - 280 (159) (Committee of Statistics).

By geography, the location of companies in the country is as follows:

- Almaty city - 89 (of which 52 are active);

-Mangistau region - 30 (17);

- Aktobe region - 27 (9);

- Kyzylorda region - 14 (8);

- Zhambyl region - 13 (9).

At the beginning of 2019, the actual number of enterprises in the production of coke and oil products amounted to 8.1 thousand people. The largest regional population (67.9\%) is concentrated in Atyrau, Pavlodar regions and the city of Shymkent. This is due to the fact that in these regions there are 3 large domestic oil refineries - the Atyrau Refinery (Atyrau), the Petroleum Refinery (Pavlodar) and the PKOP (Shymkent).

The number of employees in this area will increase significantly if we take into account the employees of enterprises for the extraction of crude oil and natural gas, which are engaged in gas processing and sale of oil and gas. 


\section{ENTREPRENEURSHIP AND SUSTAINABILITY ISSUES}

ISSN 2345-0282 (online) http://jssidoi.org/jesi/ 2019 Volume 7 Number 2 (December) http://doi.org/10.9770/jesi.2019.7.2(57)

The attractiveness of the oil and gas sector is still high due to the corresponding level of competitiveness of wages in the industry. The average monthly nominal wage of one employee for the production of coke and oil products at the end of 2018 amounted to 386966 tenge, or $165.1 \%$ of the average monthly nominal wage for one worker throughout the industry (234 413 tenge). According to this indicator, the sector under consideration is in third place, the first two places are occupied by the extraction of crude oil and natural gas and the production of tobacco products.

The salary fund for workers in the production of coke and oil products for 2018 amounted to 37.4 billion tenge ( $2.2 \%$ of the salary fund for workers throughout the industry). The salary fund for workers in the production of coke and oil products in 2018 compared to 2014 increased by $46.6 \%$, throughout the industry this indicator increased by $24.6 \%$ (JSC KIO).

\section{Results and discussions}

In Kazakhstan, in 2018, 90.4 million tons of oil and gas condensate were produced, which is a historically record volume for the country (4.8\% more than in 2017) (Table 2).

Table 2. Indicators of oil production by enterprises of the oil industry of the Republic of Kazakhstan for the period from 2012 till 2019

\begin{tabular}{|c|c|c|c|c|c|c|c|c|}
\hline \multirow[t]{2}{*}{ Indicator } & \multirow[t]{2}{*}{ Unit } & \multicolumn{7}{|c|}{ Years } \\
\hline & & 2012 & 2013 & 2014 & 2015 & 2016 & 2017 & 2018 \\
\hline Oil production & in mln tonnes & 79,2 & 81,8 & 80,8 & 79,5 & 78,0 & 86,2 & 90,4 \\
\hline GDP & in US dollars & 208,0 & 236,6 & 221,4 & 184,4 & 137,3 & 159,4 & 184,2 \\
\hline $\begin{array}{l}\text { Shipment to the } \\
\text { domestic market }\end{array}$ & $\begin{array}{l}\% \text { to the volume of } \\
\text { production }\end{array}$ & 15,8 & 16,0 & 16,3 & 17,8 & 16,8 & 15,4 & 15,9 \\
\hline
\end{tabular}

Source: compiled by authors according to Industry Analysis Report. Kazakh Institute of Oil and Gas JSC - Nur-Sultan, 2019 - p. 18

The decline in world oil prices from \$ 98 in 2014 to \$ 53 in 2015 and \$ 44 in 2016 and a slight decline in its production slowed economic growth from $4.1 \%$ in 2014 to $1.2 \%$ and $1 \%$ in 2015 and 2016 years.

Effective development of oil and gas fields is impossible without a full and comprehensive modeling of processes characterized by indicators of oil production. Therefore, we consider it necessary, in our study, to implement a multifactor model that allows us to forecast the development of the main factors listed in Table 2 above that set the level of the development trend of oil production by enterprises of the oil industry of the Republic of Kazakhstan for the period from 2012-2018.

Multivariate analysis refers to the methodology of a comprehensive and systematic study and measurement of the impact of factors on the value of effective indicators.

In studying the laws of economic phenomena, it is of great importance to identify the relationships between interrelated phenomena that develop over time, and conduct a related analysis of the dynamics. For this purpose, multi-factor models of interconnected time series are being constructed.

To develop a model, we use the method of correlation and regression analysis. Correlation represents the likely relationship between indicators that are not in a functional relationship. This method is used to determine the tightness of the relationship between indicators. 
The multiple regression equation can be represented as:

where:

$$
\mathrm{Y}=\mathrm{f}(\beta, \mathrm{X})+\varepsilon
$$

$\mathrm{X}=\mathrm{X}\left(\mathrm{X}_{1}, \mathrm{X}_{2}, \ldots, \mathrm{X}_{\mathrm{m}}\right)$ - vector of independent (explanatory) variables;

$\beta$ - vector of parameters (to be determined);

$\varepsilon$ - random error (deviation);

$\mathrm{Y}$ - dependent (explained) variable.

The theoretical linear equation of multiple regression has the form:

where:

$$
\mathrm{Y}=\beta_{0}+\beta_{1} \mathrm{X}_{1}+\beta_{2} \mathrm{X}_{2}+\ldots+\beta_{\mathrm{m}} \mathrm{X}_{\mathrm{m}}+\varepsilon
$$
to 0 .

$\beta_{0}$ - the free term that determines the value of $\mathrm{Y}$, in the case when all the explanatory variables $\mathrm{Xj}$ are equal

The empirical equation of multiple regression can be represented as:

$$
\mathrm{Y}=\mathrm{b}_{0}+\mathrm{b}_{1} \mathrm{X}_{1}+\mathrm{b}_{1} \mathrm{X}_{1}+\ldots+\mathrm{b}_{\mathrm{m}} \mathrm{X}_{\mathrm{m}}+\mathrm{e}
$$

where:

$b_{0}, b_{1}, \ldots, b_{m}$ - estimates of theoretical values $\beta_{0}, \beta_{1}, \beta_{2}, \ldots, \beta_{\mathrm{m}}$ regression coefficients (empirical regression coefficients);

e - deviation estimate $\varepsilon$.

When fulfilling the preconditions of OLS regarding errors $\varepsilon_{i}$, assessments $b_{0}, b_{1}, \ldots, b_{m}$ parameters $\beta_{0}, \beta_{1}, \beta_{2}, \ldots, \beta_{\mathrm{m}}$ multiple linear regression according to least squares are unbiased, efficient and consistent.

To estimate the parameters of the multiple regression equation, OLS is used.

We define the vector of estimates of the regression coefficients. According to the least squares method, the vector $\mathrm{s}$ is obtained from the expression: $s=\left(X^{T} X\right)^{-1} X^{T} Y$

Add a unit column to the matrix with variables $\mathrm{Xj}$ :

\begin{tabular}{|c|c|c|}
\hline & $X_{1}$ & $X_{2}$ \\
\hline 1 & 79,2 & 15,8 \\
\hline 1 & 81,8 & 16,0 \\
\hline 1 & 80,8 & 16,3 \\
\hline 1 & 79,5 & 17,8 \\
\hline 1 & 78,0 & 16,8 \\
\hline 1 & 86,2 & 15,4 \\
\hline 1 & 90,4 & 15,9 \\
\hline
\end{tabular}

Matrix $Y$

Matrix $X^{T}$

\begin{tabular}{|l|}
\hline 208,0 \\
\hline 236,6 \\
\hline 221,4 \\
\hline 184,4 \\
\hline 137,3 \\
\hline 159,4 \\
\hline 184,2 \\
\hline
\end{tabular}

\begin{tabular}{|c|c|c|c|c|c|}
\hline 1 & 1 & 1 & 1 & 1 & 1 \\
\hline 79,2 & 81,8 & 80,8 & 79,5 & 78,0 & 86,2 \\
\hline 15,8 & 16,0 & 16,3 & 17,8 & 16,8 & 15,4 \\
\hline
\end{tabular}


Multiply Matrices, $\left(X^{T} Y\right)$

$X^{T} X=$\begin{tabular}{|c|c|c|}
\hline 7,0 & 575,9 & 114,0 \\
\hline 575,9 & 47499,37 & 9367,54 \\
\hline 114,0 & 9367,54 & 1860,38 \\
\hline
\end{tabular}

In the matrix, (XTX), the number 6 lying at the intersection of the 1st row and the 1st column is obtained as the sum of the products of the elements of the 1st row of the XT matrix and the 1st column of the matrix X.

Multiply Matrices, $\left(X^{T} Y\right)$

$$
X^{T} Y=\begin{array}{|c|}
\hline 1331,3 \\
\hline 109477,76 \\
\hline 21653,32 \\
\hline
\end{array}
$$

Find the inverse matrix $\left(X^{T} X\right)^{-1}$

$\left(X^{T} X\right)^{-1}=$\begin{tabular}{|c|c|c|}
\hline 271,5 & $-1,539$ & $-8,885$ \\
\hline$-1,539$ & 0,0117 & 0,0352 \\
\hline$-8,885$ & 0,0352 & 0,368 \\
\hline
\end{tabular}

The vector of estimates of the regression coefficients is

$Y(X)=$\begin{tabular}{|l|l|l|}
\hline 271,5 & $-1,539$ & $-8,885$ \\
\hline$-1,539$ & 0,0117 & 0,0352 \\
\hline$-8,885$ & 0,0352 & 0,368 \\
\hline
\end{tabular}$*$\begin{tabular}{|l|}
\hline 1331,3 \\
\hline 109477,76 \\
\hline 21653,32 \\
\hline
\end{tabular}$=$\begin{tabular}{|l|}
\hline 514,923 \\
\hline$-1,57$ \\
\hline$-12,012$ \\
\hline
\end{tabular}

Regression equation (estimation of the regression equation)

Paired Correlation Coefficients R:

$$
Y=514,923-1,5697 \cdot X_{1}-12,0122 \cdot X_{2}
$$

$$
\begin{aligned}
& r_{x y}=\frac{\overline{x \cdot y}-\bar{x} \cdot \bar{y}}{s(x) \cdot s(y)} \\
& r_{y x 1}=\frac{15639,68-82,271 \cdot 190,186}{4,128 \cdot 32,205}=-0,539 \\
& r_{y x 2}=\frac{3093,331-16,286 \cdot 190,186}{0,738 \cdot 32,205}=-0,167 \\
& r_{x 1 \times 2}=\frac{1338,22-16,286 \cdot 82,271}{0,738 \cdot 4,128}=-0,535
\end{aligned}
$$

Dispersions and standard deviations

\begin{tabular}{|l|c|c|c|c|}
\hline \multicolumn{1}{|c|}{$\begin{array}{c}\text { Signs } \\
\mathrm{x} \text { and } \mathrm{y}\end{array}$} & $D(x)=\frac{\sum x_{i}^{2}}{n}-\bar{x}^{2}$ & $D(y)=\frac{\sum y_{i}^{2}}{n}-\bar{y}^{2}$ & $s(x)=\sqrt{D(x)}$ & $s(y)=\sqrt{D(y)}$ \\
\hline For $\mathrm{y}$ and $\mathrm{x} 1$ & 17,036 & 1037,133 & 4,128 & 32,205 \\
\hline For $\mathrm{y}$ and $\mathrm{x} 2$ & 0,544 & 1037,133 & 0,738 & 32,205 \\
\hline For $\mathrm{x}_{1}$ and $\mathrm{x}_{2}$ & 0,544 & 17,036 & 0,738 & 4,128 \\
\hline
\end{tabular}

We calculate the observed values of t-statistics for $r_{\mathrm{yx} 1}$ according to the formula: 


$$
r_{n a b l}=r_{y x 1} \frac{\sqrt{n-m-1}}{\sqrt{1-r_{y x 1}^{2}}}
$$

where:

$\mathrm{m}=1$ - number of factors in the regression equation. $r_{\text {nabl }}=0,0539 \frac{\sqrt{7-1-1}}{\sqrt{1-0,0539^{2}}}=0,12$

According to the student table we find Ttable

$\mathrm{t}_{\text {crit }}(\mathrm{n}-\mathrm{m}-1 ; \alpha / 2)=(5 ; 0,025)=2,571$

Insofar as $t_{\text {nabl }}>t_{\text {crit }}$, then we reject the hypothesis of equality of 0 correlation coefficient.

In other words, the correlation coefficient is statistically significant

We calculate the observed values of t-statistics for $\mathrm{r}_{\mathrm{yx} 2}$ according to the formula:

$r_{\text {nabl }}=0,17 \frac{\sqrt{7-1-1}}{\sqrt{1-0,17^{2}}}=0,38$

Insofar as $t_{\text {nabl }}>t_{\text {crit }}$, then we reject the hypothesis of equality of 0 correlation coefficient. In other words, the correlation coefficient is statistically significant.

Let's move on to the statistical analysis of the obtained regression equation: checking the significance of the equation and its coefficients, studying the absolute and relative approximation errors.

For an unbiased estimate of variance, we perform the following calculations:

Unbiased error $\varepsilon=Y-Y(x)=Y-X^{*} s$ (absolute error of approximation)

\begin{tabular}{|c|c|c|c|c|c|}
\hline$Y$ & $Y(x)$ & $\varepsilon=Y-Y(x)$ & $\varepsilon^{2}$ & $(Y-Y c p)^{2}$ & $|\varepsilon: Y|$ \\
\hline 208,0 & 200,808 & 7,192 & 51,723 & 317,349 & 0,0346 \\
\hline 236,6 & 194,324 & 42,276 & 1787,229 & 2154,286 & 0,179 \\
\hline 221,4 & 192,29 & 29,11 & 847,366 & 974,332 & 0,131 \\
\hline 184,4 & 176,313 & 8,087 & 65,402 & 33,474 & 0,0439 \\
\hline 137,3 & 190,68 & $-53,38$ & 2849,383 & 2796,899 & 0,389 \\
\hline 159,4 & 194,625 & $-35,225$ & 1240,79 & 947,76 & 0,221 \\
\hline 184,2 & 182,026 & 2,174 & 4,727 & 35,829 & 0,0118 \\
\hline & & & 6846,62 & 7259,929 & 1,01 \\
\hline
\end{tabular}

Estimation of standard deviation (standard error for estimating Y): $S=\sqrt{S^{2}}=41,372$

The tightness of the combined influence of factors on the result is estimated by the multiple correlation index. Unlike the pair correlation coefficient, which can take negative values, it takes values from 0 to 1 .

Therefore, $\mathrm{R}$ cannot be used to interpret the direction of communication. The denser the actual values $y_{i}$ are located relative to the regression line, the smaller the residual variance and, therefore, the larger the value

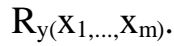

Thus, when the value of $\mathrm{R}$ is close to 1 , the regression equation better describes the actual data and factors have a stronger effect on the result. With an $\mathrm{R}$ value close to 0 , the regression equation poorly describes the evidence and factors have little effect on the result.

Multiple correlation coefficient

$$
R=\sqrt{1-\frac{6846,62}{7259,93}}=0,2386
$$

The link between $\mathrm{Y}$ attribute and $\mathrm{Xi}$ factors is strong 
We will calculate the correlation coefficient using the known values of the linear coefficients of pair correlation and $\beta$-coefficients. $R=\sqrt{\sum r_{y x i} \beta_{y x i}}=\sqrt{r_{y x 1} \beta_{y x 1}+r_{y x 2} \beta_{y x 2}}$

$$
R=\sqrt{(-0,0539) \cdot(-0,201)+(-0,167)(-0,275)}=\sqrt{0,0569}=0,239
$$

The significance of the multiple regression equation is estimated by testing the hypothesis that the determination coefficient calculated from the data of the general population is equal to zero: $\mathrm{R} 2$ or $\mathrm{b} 1=\mathrm{b} 2=\ldots=\mathrm{bm}=0$ (the hypothesis of the insignificance of the regression equation calculated from the data of the general population).

To test it, use the Fisher F-test.

In this case, the actual (observed) value of the F-criterion is calculated through the determination coefficient R2, calculated according to the data of a specific observation.

The critical value of the F-criterion (Fcr) is found from the Fisher-Snedocor distribution tables. For this, they are set by the significance level $\alpha$ (usually it is taken equal to 0.05 ) and two numbers of degrees of freedom $\mathrm{k} 1=\mathrm{m}$ and $\mathrm{k} 2=\mathrm{n}-\mathrm{m}-1$.

Let us verify the hypothesis of general significance - the hypothesis of the simultaneous equality to zero of all regression coefficients with explanatory variables:

$\mathrm{H}_{0}: \mathrm{R}^{2}=0 ; \beta_{1}=\beta_{2}=\ldots=\beta_{\mathrm{m}}=0$.

$\mathrm{H}_{1}: \mathrm{R}^{2} \neq 0$.

This hypothesis is tested using F-statistics of the Fisher distribution (right-hand check).

If $\mathrm{F}<\mathrm{F}_{\mathrm{kp}}=\mathrm{F}_{\alpha ; \mathrm{n}-\mathrm{m}-1}$, there is no reason to reject the hypothesis $\mathrm{H}_{0}$.

$$
F=\frac{R^{2}}{1-R^{2}} \frac{n-m-1}{m}=\frac{0,05693}{1-0,05693} \frac{7-2-1}{2}=0,121
$$

Table value with degrees of freedom $\mathrm{k}_{1}=2$ и $\mathrm{k}_{2}=\mathrm{n}-\mathrm{m}-1=7-2-1=4, \operatorname{Fcr}(2 ; 4)=6,94$

Since the actual value is $\mathrm{F}>\mathrm{Fcr}$, the determination coefficient is statistically significant and the regression equation is statistically reliable (the joint significance of the coefficients for factors $\mathrm{x}_{\mathrm{i}}$ is confirmed).

Table 3. Predicted values of indicators of oil production by enterprises of the oil industry of the Republic of Kazakhstan for the period from 2019-2021

\begin{tabular}{|l|c|c|c|}
\hline \multicolumn{1}{|c|}{ Index } & 2019 & 2020 & 2021 \\
\hline Oil production, in million tons & 87,929 & 89,343 & 90,757 \\
\hline GDP, billion US dollars & 145,91 & 134,85 & 123,78 \\
\hline $\begin{array}{l}\text { Shipment to the domestic market,\% of the } \\
\text { volume of production }\end{array}$ & 16,229 & 16,214 & 16,2 \\
\hline
\end{tabular}

Source: compiled and calculated by authors

As a result of the calculations, the multiple regression equation was obtained:

$$
Y=514,923-1,5697 \quad X_{1}-12,0122 \quad X_{2}
$$

Possible economic interpretation of model parameters: increase $X_{1}$ for 1 unit leads to a decrease $Y$ on average 1,57 units; increase $X_{2}$ for 1 unit leads to an increase in $\mathrm{Y}$ by an average of 12.012 units. By maximum ratio $\beta_{1}=-$ 0,201 we conclude that the factor has the greatest influence on the result $\mathrm{Y}$ and $X_{1}$. 
The statistical significance of the equation was verified using the coefficient of determination and the Fisher test. It was found that in the studied situation, $100 \%$ of the total variability of Y is explained by a change in factors $X_{I}$ and $X_{2}$. It was also established that the model parameters are statistically weakly expressed.

If we look at the regional aspect of oil production, including gas condensate for the period 2014 - 2018, the predominant part is occupied by the Atyrau and Mangistau regions (Table 4).

Table 4. Indicators of oil production in the regions of Kazakhstan, including gas condensate for the period 2014 - 2018 (thousand tons)

\begin{tabular}{|l|c|c|c|c|c|}
\hline \multirow{2}{*}{ Region } & \multicolumn{3}{c|}{ Years } & 2017 & 2018 \\
\cline { 2 - 6 } & 2014 & 2015 & 2016 & 86194,4 & 90354,2 \\
\hline Republic of Kazakhstan & 80825,6 & 79456,3 & 78031,8 & 5985,9 & 5985,5 \\
\hline Aktuibinsk & 7352,9 & 6814,1 & 6202,9 & 42230,2 & 47213,6 \\
\hline Atyrau & 31943,2 & 32390,3 & 33680,7 & 13162,4 & 12691,7 \\
\hline West Kazakhstan & 13061,0 & 12748,2 & 12347,1 & 20,6 & 18,9 \\
\hline Zhambyl & 20,7 & 18,5 & 20,8 & 6813,9 & 6393,3 \\
\hline Kyzylorda & 9919,8 & 8974,2 & 7669,3 & 17981,3 & 18050,9 \\
\hline Mangystau & 18527,2 & 18510,1 & 18110,2 & 0,1 & 0,3 \\
\hline East Kazakhstan & 0,8 & 0,9 & 0,9 & & \\
\hline
\end{tabular}

Source: compiled by authors on the basis of the source: Industry Analysis Report of JSC Kazakh Institute of Oil and Gas. Nur-Sultan, 2019. 29p.

As a percentage of the previous year, indicators of oil production in Kazakhstan are also shown, including gas condensate for the period 2014 - 2018, as well as forecast values for the period from 2019-2021, where there is a steady increase in this indicator (Figure 1).

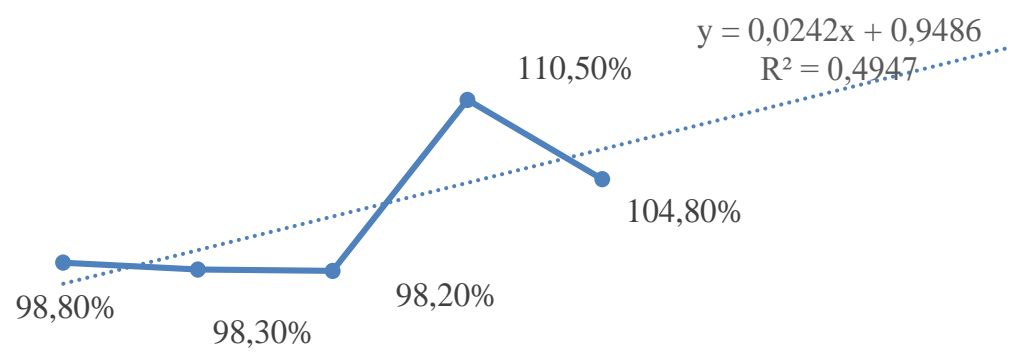

$\begin{array}{ccccc}\text { in } \% \text { to } & \text { in } \% \text { to } & \text { in } \% \text { to } & \text { in } \% \text { to } & \text { in } \% \text { to } \\ 2014 & 2015 & 2016 & 2017 & 2018\end{array}$

Figure 1. Indicators of oil production in Kazakhstan, including gas condensate for the period 2014 - 2018, as well as the forecast for the next 3 years

Source: compiled by authors 


\section{ENTREPRENEURSHIP AND SUSTAINABILITY ISSUES}

ISSN 2345-0282 (online) http://jssidoi.org/jesi/

2019 Volume 7 Number 2 (December)

http://doi.org/10.9770/jesi.2019.7.2(57)

Thus, the priority is the full provision of the domestic market with fuels and lubricants in accordance with the new environmental standards by 2025 . We also note the strategic objectives of the development of the oil complex, indicated in the Concept of development of the fuel and energy complex of the Republic of Kazakhstan until 2030:

1) attracting investment in exploration and effective technological development of oil production;

2) ensuring energy security for key types of petroleum products, full coverage of domestic demand for motor fuels and lubricants;

3) consistent liberalization of oil refining and the oil product market;

4) promoting integration into international associations, preparing for integration into the CES;

5) the development of human resources in the oil and gas sector (Aimagambetov and Kuttybaeva 2016).

In 2018, in the oil refining sector, modernization projects for oil refineries were fully completed. The capacity and depth of processing have been increased, the quality of petroleum products complies with European standards K4, K-5. The volume of oil refining increased by $8.6 \%$ compared to 2017 and amounted to 16.4 million tons (including "Condensate" and "CaspiBitum"). It is planned to process 17.2 million tons this year, which is 5\% more than in 2018.

The modernization of three large refineries allowed Kazakhstan to get rid of dependence on Russian supplies, moreover, in the summer of 2018, Astana introduced a ban on gasoline import from the Russian Federation in order to prevent overstocking of the tanks of three large Kazakhstani refineries with oil products.

In connection with the development of the oil industry in Kazakhstan, one of the important issues in the development of the oil and gas industry, like any industry, is the issue of its staffing. The attractiveness of the oil and gas sector is still high due to the corresponding level of competitiveness of wages in the industry. Trends in the development of digitalization and automation in the oil and gas industry are leading to the creation of databases and data processing centers (bigdata), which will require retraining of employees taking into account new requirements and knowledge. Today, most production processes at oil and gas enterprises are automated, but at the same time, the person has the right to make the most responsible decisions.

For example, a specialist working with smart field technologies can monitor technological parameters in real time, and also, if necessary, manually control technological processes. "The availability of labor resources for the implementation of the digitalization program in the oil and gas industry remains low. In this regard, training and attracting specialists is one of the pressing issues of the industry. The emergence of new professions and positions related to "intellectual fields" is possible both in the IT and oil and gas sectors.

In this regard, in the near future, key professions will be associated with oil and gas exploration (including drilling exploratory wells, geological and geophysical work, etc.), increasing production efficiency (including through new technologies and applying methods of increasing oil recovery).

In 2016-2017, the Ministry of Energy of the Republic of Kazakhstan, together with the KAZENERGY Association, also carried out work to develop the Sector Qualifications Framework for the oil and gas, oil refining and petrochemical industries, and on March 30, 2017, this ORC was approved at a meeting of the Sectoral Commission on Social Partnership and the Regulation of Social and Labor Relations of the Oil and Gas Industry. In addition, the Order of the NPP Atameken RK No. 312 dated November 20, 2018 approved the professional standards: "Drilling team", "Installation work", "Drilling management". 4. Oil and gas processing companies of the Republic of Kazakhstan in their activities use the industry-wide Qualification Directory of the positions of managers, specialists and other employees, the All-Union Classifier of Occupations of Workers, Positions of Employees and Rate Categories, the Unified Tariff and Qualification Directory of Work and Occupations of Workers and the Classification of Occupations of the Republic of Kazakhstan. 


\section{ENTREPRENEURSHIP AND SUSTAINABILITY ISSUES}

ISSN 2345-0282 (online) http://jssidoi.org/jesi/

2019 Volume 7 Number 2 (December)

http://doi.org/10.9770/jesi.2019.7.2(57)

The concept for the development of the fuel and energy complex (FEC) until 2030, developed in June 2014, is a key document that defines the strategic goals of the exploration and production sector. According to this concept, in the future, until 2030, the oil industry will:

1) created economic incentives to attract investment in geological exploration and the effective technological development of oil production;

2) the personnel potential of the oil and gas industry is ensured;

3) technology transfer was provided in the oil production segment;

4) the domestic market for petroleum products is provided, oil refining capacities are expanded;

5) a competitive market for petroleum products and refining is developed.

Currently, Kazakhstan has a comprehensive system for attracting foreign labor:

- quota system for qualified foreign labor and labor immigrants;

- multistage system for issuing work permits.

Within the framework of the Eurasian Economic Union, a regime of free movement of labor resources in the territory of member states is in force.

In 2016-2017, the Ministry of Energy of the Republic of Kazakhstan, together with the KAZENERGY Association, also carried out work to develop the Sector Qualifications Framework for the oil and gas, oil refining and petrochemical industries, and on March 30, 2017, this ORC was approved at a meeting of the Sectoral Commission on Social Partnership and the Regulation of Social and Labor Relations of the Oil and Gas Industry. In addition, the Order of the NPP Atameken RK No. 312 dated November 20, 2018 approved the professional standards: "Drilling team", "Installation work", "Drilling management". 4. Oil and gas processing companies of the Republic of Kazakhstan in their activities use the industry-wide Qualification Directory of the positions of managers, specialists and other employees, the All-Union Classifier of Occupations of Workers, Positions of Employees and Rate Categories, the Unified Tariff and Qualification Directory of Work and Occupations of Workers and the Classification of Occupations of the Republic of Kazakhstan.

The concept for the development of the fuel and energy complex (FEC) until 2030, developed in June 2014, is a key document that defines the strategic goals of the exploration and production sector. According to this concept, in the future, until 2030, the oil industry will:

1) created economic incentives to attract investment in geological exploration and the effective technological development of oil production;

2) the personnel potential of the oil and gas industry is ensured;

3) technology transfer was provided in the oil production segment;

4) the domestic market for petroleum products is provided, oil refining capacities are expanded;

5) a competitive market for petroleum products and refining is developed.

Currently, Kazakhstan has a comprehensive system for attracting foreign labor:

- quota system for qualified foreign labor and labor immigrants;

- multistage system for issuing work permits.

Within the framework of the Eurasian Economic Union, a regime of free movement of labor resources in the territory of member states is in force.

\section{Conclusions}

Today, partnerships can only be observed in the field of highly qualified rare professions, where employers are willing to make concessions to employees in order to attract specialists. In such areas, the presence of collective labor contracts and even partial, but their implementation. Therefore, for the implementation of social partnership, a high level of labor potential of both an individual employee and the aggregate labor force is necessary. At the same time, labor potential without an established system of social partnership is not capable of developing. 


\section{ENTREPRENEURSHIP AND SUSTAINABILITY ISSUES}

ISSN 2345-0282 (online) http://jssidoi.org/jesi/

2019 Volume 7 Number 2 (December)

http://doi.org/10.9770/jesi.2019.7.2(57)

The oil industry of Kazakhstan is not only the most important industry, it is one of the main components of the economic security of the country, its independence. Tax revenues from the development of oil fields and the sale of oil allow for the implementation of social programs and strengthen domestic political stability.

Having emerged as a mechanism for resolving labor disputes, and having proved its effectiveness, social partnership is increasingly turning into an instrument of public participation in solving social problems. On this basis, further effective development of the system of social partnership will contribute to the balance of interests in society with the aim of relieving social tension and ensuring social and political stability of the society.

Oil companies-subsoil users are important and active agents of economic and social development, as they receive income from the development and use of oil fields in Kazakhstan. According to the contracts concluded with subsoil users, they are obliged not only to use goods and services produced by domestic producers in their activities, to attract Kazakhstani personnel to carry out the work, but also to train Kazakhstani specialists at the expense of the received income from subsoil use.

For example, JSC NC "KazMunayGas" conducts continuous monitoring on the issues of retraining and advanced training of engineering and managerial staff for the preparation and conduct of projects for the development of the Kazakhstan sector of the Caspian Sea. The funds allocated by him for the training of his own staff are directed to the development of new technologies in the oil and gas industry and internships in large oil and gas companies.

"The first positive social effect of the activities of subsoil user companies in Kazakhstan can be attributed to their contribution to the education and training of Kazakhstani employees of these companies (direct effect), thereby increasing the number of qualified Kazakhstanis in the total number of personnel of these companies (direct effect), which can compete with foreign specialists (indirect effect). KAZENERGY, the Kazakhstan Association of Oil and Gas and Energy Complex Organizations, has been extremely active and responsible in creating and implementing educational programs for the oil and gas sector of Kazakhstan. In which the coordinating Council on education and personnel issues was created. The Council determines the roles, the measure of responsibility and the participation of employers in organizing the process of professional training of competitive personnel, and developing proposals that contribute to improving the quality of specialist training. The republic has a number of higher education institutions providing quality staffing, as well as educational programs of the Association of Energy Sector Enterprises KAZENERGY.

Today, the industry is faced with an important problem - a lack of highly qualified specialists. The rapid development of engineering and technology requires extensive training and retraining of the entire personnel of companies. The level of knowledge with which a young specialist comes to work in the company leaves much to be desired, which shows an imbalance between the requirements of companies for the qualifications of graduates of educational institutions and the content of training programs. To improve the quality of qualifications and provide work for graduates, large oil and gas companies have cooperation agreements with relevant universities in the country.

Thus, it should be noted that social partnership is one of the criteria for the democratization of society. It is aimed at ensuring, on the basis of equal cooperation, the real participation of workers, employers and the state in the development and adoption of socio-economic and labor policies based on the optimal balance of the interests of the parties. To ensure this balance, of course, it is necessary to have a rule of law state in which all relations must be regulated by democratic laws. The system of social partnership will actually fulfill its functions if democratic principles are respected, that is, various social groups will be given the opportunity to defend their interests and rights within the framework of the law. 


\section{ENTREPRENEURSHIP AND SUSTAINABILITY ISSUES}

ISSN 2345-0282 (online) http://jssidoi.org/jesi/

2019 Volume 7 Number 2 (December)

http://doi.org/10.9770/jesi.2019.7.2(57)

\section{References}

Aimagambetov, Ye. B., Kuttybaeva N. 2016. Assessing the level of competitiveness of the Republic of Kazakhstan on the basis of world rankings analysis. International Journal of Economic Perspectives, 10(3): 101-112.

Aitbay, K. 2014. Development of social partnership in modern Kazakhstan: problems and prospects. Republican Socio-Political Journal Thought, 10 (14): 31-36.

Amrebaev, A. 2015. Kazakhstan in the conditions of world social instability: the search for an adaptive model of overcoming the social crisis. Kazakhstan in Global Processes, 1(9): 69-75.

Constitution of the Republic of Kazakhstan. 1995. As amended and supplemented as of March 23, 2019.

Electronic resource: Data of the Committee on Statistics of the Republic of Kazakhstan for 2014-2018. www.stat.gov.kz

Electronic resource: Data of the Federation of Trade Unions of the Republic of Kazakhstan, www.fprk.kz

Electronic resource: Data of the Ministry of Energy of the Republic of Kazakhstan. www.energo.gov.kz

Electronic resource: http://www.enbek.gov.kz/ru/node/251829

Official Internet resource of the Ministry of Labor and Social Protection of the Population of the Republic of Kazakhstan. On the development of social partnership in Kazakhstan.

Electronic resource: Publications of JSC “Development of labor resources”. https://iac.enbek.kz/ru/publications

Gordon, E.A. 2015. On the way to social partnership: the development of social and labor relations in modern Russia. Moscow. 225p.

Industry agreement in the oil and gas, oil refining and petrochemical sectors of the Republic of Kazakhstan for 2017-2019. Approved by the Protocol of the Industry Commission for Social Partnership and the Regulation of Social and Labor Relations of the Oil and Gas Industry, 4(11): 201-206.

Industry analysis report. 2019. JSC Kazakh Institute of Oil and Gas. Nur-Sultan. 19p.

Kupbaev, S.I. 2018. Social partnership as a basis for balancing the interests of labor market entities. KAZENERGY, 2(87): 82-86.

Law of the Republic of Kazakhstan on Trade Unions. 2017.

Leontieva, A.G. 2017. Social partnership as an institute of market economics. Moscow. 199p.

Mukhambetova, L.K. 2014. Ensuring labor safety and security within the framework of social partnership. Bulletin, 2(11): 28-34.

Peregudov, S.P. 2016. New economic structures and the Russian state. Russia and the modern world, 2(11): 49-54.

Pshenichny, S.P. 2015. Development Trends of the Institute of Social Partnership in Russia. Economic Sciences, 12(109): 47-51.

Shaltykov, A.I. 2015. Social partnership as a way of ensuring the stability of society. Bulletin of KazNPU, 2(9): 19-25.

Sycheva, I.K. 2016. Labor relations in the structure of economic systems (methodological aspect). Tomsk. 136p.

Voeikov, M., Lashchinsky, I. 2016. Illusions of social partnership. Alternatives, 2 (9):45-49.

Winds, A.B. 2015. Rivalry or partnership. Moscow. 199p. 
ENTREPRENEURSHIP AND SUSTAINABILITY ISSUES

ISSN 2345-0282 (online) http://jssidoi.org/jesi/

2019 Volume 7 Number 2 (December)

http://doi.org/10.9770/jesi.2019.7.2(57)

Alisher SANSYZBAYEV is the PhD student of Narxoz University, Almaty, Kazakhstan. Research interests: entrepreneurship and social development; innovations; oil industry.

ORCID ID: orcid.org/0000-0002-5097-7990

Register for an ORCID ID:

https://orcid.org/register

Copyright (C) 2019 by author(s) and VsI Entrepreneurship and Sustainability Center

This work is licensed under the Creative Commons Attribution International License (CC BY).

http://creativecommons.org/licenses/by/4.0/

(c) (i) Open Access 